\title{
Secrets of a Sorceress: Tasso's Armida
}

Armida appears in Canto 4 of Torquato Tasso's Gerusalemme liberata. Her mission? To disseminate confusion in the Christian camp. This she accomplishes with expert techniques. She is both sorceress and seductress, like the characters of classical and Renaissance literature on whom her character is modelled: Circe, Medea, Alcina, and so forth. But though Armida is introduced as a sorceress and has infernal and magical connections through her uncle Idraote, she does not rely on her magic in order to entice the Christian soldiers into accompanying her and therefore abandoning their cause. Magic is not what keeps Rinaldo, the Christian warrior with whom she falls in love, in her power; nor is Armida's magic effective when Rinaldo abandons her in Canto 16. Thus it seems that Armida's magical powers come to be viewed as a function of youth and sexual charm, which can fade. But even youth and sexuality, important as they are to Armida's temporary victory, do not fully explain the tenacity of her hold on her Christian opponents. Armida's power over the Christian warriors is particularly strong precisely because neither magic nor sexuality is her primary tool, and because her victims remain unaware of the source of her power. As I propose to show here, Armida's initial triumphs over the Christians and the fascination she exercises as a character derive from the unthreatened superiority of her gaze and from her control of the linguistic medium, in particular from the irrefutability of the story she narrates about her origins.

When Armida first sets out to fulfill the task set for her by Idraote, she keeps herself out of sight ("L'impresa prende, e in su la prima sera/ parte e tiene sol vie chiuse e celate" $[4.27 .3-4]){ }^{1}$ She is described more fully only when she arrives in the Christian camp:

Argo non mai, non vide Cipro o Delo

d'abito o di beltà forme sí care.

D'auro ha la chioma, ed or dal bianco velo

traluce involta, or discoperta appare:

cosí, qualor si rasserena il cielo, 
or da candida nube il sol traspare, or da la nube uscendo i raggi intorno piú chiari spiega, e ne raddoppia il giorno.

Fa nove crespe l'aura al crin disciolto, che natura per sé rincrespa in onde; stassi l'avaro sguardo in sé raccolto, e i tesori d'amore e i suoi nasconde. Dolce color di rose in quel bel volto fra l'avorio si sparge e si confonde: ma ne la bocca ond'esce aura amorosa, sola rosseggia e semplice la rosa.

Mostra il bel petto le sue nevi ignude, onde il foco d'Amor si nutre e desta. Parte appar de le mamme acerbe e crude, parte altrui ne ricopre invida vesta; invida, ma s'a gli occhi il varco chiude, l'amoroso pensier già non arresta, ché non ben pago di bellezza esterna ne gli occulti secreti anco s'interna.

Come per acqua o per cristallo intero trapassa il raggio, e no 'l divide o parte, per entro il chiuso manto osa il pensiero sí penetrar ne la vietata parte.

Ivi si spazia, ivi contempla il vero di tante meraviglie a parte a parte; poscia al desio le narra e le descrive, e ne fa le sue fiamme in lui piú vive.

Lodata passa e vagheggiata Armida fra le cupide turbe, e se n'avede. No 'l mostra già, benché in suo cor ne rida, e ne disegni alte vittorie e prede. (4.29.1-33.4)

The reader's sense of the nature of Armida's powers is strongly conditioned by the parallels and contrasts between Armida here and Sofronia in Canto 2 of the Gerusalemme liberata, as she moves forth through a crowd to declare herself guilty of having stolen and burned the icon of the Virgin missing from the mosque: ${ }^{2}$

La vergine tra 'l vulgo uscí soletta, non coprí sue bellezze, e non l'espose, raccolse gli occhi, andò nel vel ristretta, con ischive maniere e generose.

Non sai bene dir s'adorna o se negletta, se caso od arte il bel volto compose.

Di natura, d'Amor, de' cieli amici 
le negligenze sue sono artifici.

Mirata da ciascun passa, e non mira

l'altera donna e innanzi al re se 'n viene. (2.18.1-19.2)

Sergio Zatti argues that there is hardly any difference between Sofronia and Armida: "Eppure è soltanto un differente grado di consapevolezza del proprio fascino a distinguere Sofronia ... da Armida ..." (42). This difference in awareness is more than awareness of one's own desirability, and it is no "mere" difference. Unlike Armida, Sofronia does not invite reflection on her desirability; but more important, Sofronia does not command an active gaze. It is Love, seeing and unseeing, that assumes the active role here and controls our gaze. Love directs Olindo's gaze where Sofronia alone would never have brought it:

Amor, ch'or cieco, or Argo, ora ne veli

di benda gli occhi, ora ce gli apri e giri,

tu per mille custodie entro a i piú casti

verginei alberghi il guardo altrui portasti. (2.15.5-8)

Sofronia shows no response to Olindo: "o lo sprezza, o no 'l vede, o non s'avede" (2.16.6).

It is also worth noting that the qualities in Armida that invite the gaze of the Christian soldiers are represented by means of images that are natural and cosmological. ${ }^{3}$ The appearance of Armida is likened to that of a "cometa o stella" (4.28.5); her hair partially hidden by her veil is compared to the sun which emerges from behind the clouds; she has the "natural" attributes of the Petrarchan Laura: hair of gold, face of ivory and rose, rose mouth, snowy breasts that kindle passionate fires. Sofronia's physical attributes, on the other hand, are never described. Her virtues are "tra le mura / d'angusta casa" (2.14.5-6), and an insistent gaze brings Olindo "a i piú casti / verginei alberghi” (2.15.7-8). The contrast between Sofronia and Armida here evokes the structural principle that A. Bartlett Giamatti has identified as central to the Gerusalemme liberata: the distinction between City and Nature (183 ff.). ${ }^{4}$

The association of Sofronia with the enclosed spaces of the city, and of Armida with Nature, as well as their differing degree of awareness of the power of their own physical presence and their gaze, permit the public to take different liberties as it views these women. The spectator remains in a state of suspension when he gazes upon Sofronia. His gaze is blocked at the surface by the lack 
of specific description, by the suggestion that further speculation would be a violation of an internal space akin to defloration, and by uncertainty about what he sees which is also attributed to the general reading public ("Non sai ben dir s'adorna o se negletta, / se caso od arte il bel volto compose" [2.18.5-6]). The lengthy description of Armida, on the other hand, encourages the spectator to gaze upon her body; her association with Nature serves to mitigate the evident voyeurism (indeed, what is inappropriate about gazing at Nature?); and the spectator is not called upon to question what he sees. Once his gaze penetrates beyond the initial barrier of Armida's veil, the spectator exults in the lack of restraints. No narrow walls, no narrow house here-simply the vast spaces of the imagination.

The Christian soldiers, excited by the play of ambiguity in Armida's presence, fail to see the true Armida. Their observation of Armida creates a blazon with strong Petrarchan echoes. Other codes of bodily description would perhaps be more appropriate for Armida, in whom the conflict of surface and depth has been evident since her uncle's first address to her: "O diletta mia, che sotto biondi / capelli e fra sí tenere sembianze / canuto senno e cor virile ascondi" (4.24.13 ). For example, according to the precepts of physiognomical treatises, observation of the body should lead to the truth about a man's character, for-as physiognomy states repeatedly-the changes and dispositions manifest in the body we see reflect changes and dispositions in that which we cannot see, namely the soul. The penetrating thought that ought to reveal the hidden secrets of the soul suddenly takes a different direction as the movement from body surface to depths of soul is replaced by the movement from body surface to an erotic locus. One senses a certain irony when Tasso's narrator notes how the observers contemplate "il vero/ di tante meraviglie a parte a parte ..." (4.32.5-6, emphasis mine) beneath Armida's mantle, just as one senses a tongue-in-cheek quality when Ariosto's narrator says of Alcina's palace, "a me par oro, poi che sí risplende" (Orlando furioso, 7.59.8).

Here, as elsewhere in the poem, Tasso's narrator presents himself as more knowledgeable than the characters of the poem, more aware of ambiguity, and always sensitive to the play of truth and falsehood in every division of surface and depth. The narrator's gaze follows, with appropriate ironic distance, that of the Christian soldiers. But 
both the Christian warriors and the narrator fail to look at a crucial detail: Armida's eyes. ${ }^{5}$ Though the description of Armida is rendered in context of the tradition of the blazon and in terms which are explicitly Petrarchan, no mention is made, significantly enough, of this bodily feature which physiognomical treatises have always recognized as crucial to the interpretation of character. In a genealogical line that goes back to Polemon, physiognomical treatises privilege the eyes as the most important signs of character. Della Porta, for example, notes: "il trattar de gl'occhi è il maggior, e piú importante negotio di tutta la Fisonomia" (114). Avoiding mention of Armida's eyes is all the more peculiar given that Tasso is a poet who pays a great deal of attention to eyes and to vision. ${ }^{6}$ Without looking at Armida's eyes, an observer has no way of judging her character. Somewhat later, Eustazio turns to look at Armida's eyes ("Come al lume farfalla, ei si rivolse / a lo splendor de la beltà divina, / e rimirar da presso i lumi volse" (4.34.1-3), but, caught in the web of blind physical desire, Eustazio remains the passive victim of the power of those eyes: "ne trasse gran fiamma e la raccolse / come da foco suole esca vicina" (4.34.5-6). Unreflective nature triumphs over reason because it masks itself as reason and even as a supernatural force. Thus, the verses in which the spectator's gaze is led to penetrate beneath the surface barrier of Armida's veil and mantle ("Come per acqua," etc.) recall Dante's passage from the world of nature into the world of the supernatural in Paradiso 2.34-36: "Per entro sé l'etterna margarita / ne ricevette, com'acqua recepe / raggio di luce permanendo unita." But Armida's "supernatural" attractions remain unconducive to objective description and merely allow the observer to be overcome by his own desire.

Goffredo and Tancredi remain immune to Armida's deceptions. Tancredi already has his mind engaged elsewhere, and Goffredo is not the type to be easily overcome by Armida's charms. But what keeps Goffredo from unmasking Armida? Goffredo fails to see into Armida's ruse because he fails to look at her at all. When Armida ends her plea, Tasso describes Goffredo thus: "ei cosí dubbioso a terra vòlto / lo sguardo tiene, e '1 pensier volve e gira" (4.67.1-2). Armida, on the other hand, knows that the examining gaze is of utmost importance. She observes Goffredo intently here ("la donna in lui s'affisa, e dal suo volto / intenta pende e gli atti osserva e 
mira" [4.67.3-4]), just as later she will take in every detail about the Crusaders ("Ella, che 'n essi mira aperto il core, / prende vedendo ciò novo argomento" [5.70.1-2]). Armida's ability to see without being seen is monumentalized in the presentation of her and her castle:

Splende il castel come in teatro adorno

suol fra notturne pompe altera scena,

ed in eccelsa parte Armida siede,

onde senz'esser vista e ode e vede. (7.36.5-8)

Goffredo originally decides against Armida, but then overturns his decision after hearing the declaration of the Christian soldiers determined to aid her. Perhaps Goffredo's decision to aid Armida, which ultimately threatens the success of the Crusade, is not born of his failure to look at her, but the fact is that on other occasions, Goffredo is much more attentive to his interlocutors. In Canto 2, Goffredo responds to the pagan Alete, who together with Argante has undertaken a mission to try to dissuade Goffredo from participating in the Crusade:

Il capitan rivolse gli occhi in giro

tre volte e quattro, e mirò in fronte i suoi,

e poi nel volto di colui gli affisse

ch'attendea la risposta, e cosí disse. . . . (2.80.5-8)

Later, when the Christian warriors are about to depart with Armida, Goffredo calls them to his tent (7.57); he attempts in vain to control the situation with his gaze:

Goffredo intorno gli occhi gravi e tardi volge con mente allor dubbia e sospesa, né, perché molto pensi e molto guardi,

atto gli s'offre alcuno a tanta impresa. (7.58.1-4)

$\mathrm{He}$ is nevertheless able in this case to read the warriors' inner emotional state: "Al silenzio, a l'aspetto, ad ogni segno, / di lor temenza il capitano s'accorse" (7.60.1-2).

In general, to the king or the captain of forces, as to God, is attributed the power to see beyond appearances, into the hearts of men, and therefore to make proper and just decisions. ${ }^{7}$ Armida is not thwarted in Canto 4, because it is Armida-not the Christian warriors - to whom are attributed superior powers of vision.

Armida's artfully constructed story further secures her victory. She tells of how she was born to Arbilano and Cariclia, rulers of Damascus, how she was orphaned and left in the custody of an un- 
named, power-hungry uncle, and how she has since been persecuted by that uncle. By presenting herself as a solitary, helpless, dispossessed orphan, she appeals to everything that supports the Christian soldiers' code of behavior: their sense of honor, duty, justice and family. To this point I will return shortly. Here I am interested in how Armida validates her tale by calling attention to the potential duplicity of all those around her, and highlighting her own ability to see evil in others. At first she calls attention to the uncertainty concerning the motives of her uncle:

Preso dunque di me questi il governo, vago d'ogni mio ben si mostrò tanto che d'incorrotta fé, d'amor paterno e d'immensa pietade ottenne il vanto, o che ' 1 maligno suo pensiero interno celasse allor sotto contrario manto, o che sincere avesse ancor le voglie, perch'al figliuol mi destinava in moglie. (4.45)

Armida's ability to interpret seems to improve as her story unfolds. Duplicity is portrayed in terms that suggest that interpretation according to the rules of physiognomical discourse would lead to revelation of true character and true motives. Of the cousin destined for her in marriage, Armida says, "sotto diforme aspetto animo vile, e in cor superbo avare voglie accese" (4.46.5-6). And when Armida refuses to consent to the marriage, she sees her uncle depart

con un sembiante oscuro,

onde l'empio suo cor chiaro trasparve;

e ben l'istoria del mio mal futuro

leggergli scritta in fronte allor mi parve. (4.48.1-4)

In both of these cases, Armida's interpretation of physiognomy is based on the premise that there is a clear connection between outward expression and inner emotion. Neither of Armida's two examples poses the rather more intriguing case of a physiognomy that presents conflicting interpretations or even lies about a man's inner character. In any case, the details regarding the precepts of physiognomical interpretation become superfluous, for the Christians ignore the example Armida sets when she interprets character by attending to physiognomy.

Armida then tells of her night-time dream apparitions:

Spesso l'ombra materna a me s'offria, 
pallida imago e dolorosa in atto, quanto diversa, oimè!, da quel che pria visto altrove il suo volto avea ritratto!

"Fuggi, figlia,- dicea-morte sí ria che ti sovrasta omai, pàrtiti ratto, già veggio il tòsco e '1 ferro in tuo sol danno apparecchiar dal perfido tiranno." (4.49)

Armida calls attention to her manifest ability to interpret these signs as well ("un fatale orror ne l'alma impresso / m'era presagio de' miei danni espresso" [4.48.7-8]). The truth value of these visions, which might be put into doubt, is reinforced by the similarity between Armida's dream and the dreams of two characters in Virgil's Aeneid: Dido's dream of Sichaeus, ${ }^{8}$ and Aeneas' dream of Hector. ${ }^{9}$ Both Dido and Aeneas take heed of the counsel of their male dream interlocutors, who encourage them to flee in order to preserve or found their legitimate kingdoms. The presence of the Virgilian subtexts serves to support Armida's claim to legitimacy-familial, political, and epistemological.

Armida's triumph over the Crusaders, assured by her superior vision, depends on her sexual charm, her proclamations against deception, and her expert manipulation of the Crusaders' sense of family ties. Moreover, it is crucial here that Armida tells of her own family origins in a story whose truth value cannot be determined. The reader knows independently of Armida that she has an uncle, Idraote, who rules Damascus; but the reader has no information concerning her parents other than that which Armida herself provides in the story she tells Goffredo. In the Gerusalemme conquistata, however, the narrator informs the reader that Armida's mother is a siren as soon as Armida is introduced in the poem (5.24-25). The narrator makes no mention there of a father; indeed, one is led to believe that the sirens reproduce in something of the way that Amazons do: by mating with many men so that it is impossible to tell who the father is. Thus, when Armida later announces that she is the daughter of Arbilano and an unnamed woman who brings Arbilano the kingdom of Fenicia $(G c, 5.45)$, the reader is inclined to suspect a ruse. But in the Gerusalemme liberata, Armida is in control of all such information about her origins. Even Goffredo responds to the apparent legitimacy of her claim ("in lui pietoso affetto / si desta, che non dorme in nobil petto" (4.65.7-8)), and promises her to reinstate her 
on the throne of Damascus after the proper goal of the Crusade has been won (4.69).

Tasso's own fascination with the possibility of having a free hand to recount one's own family origins reveals itself in the display of names in Armida's tale. The names of Armida's parents and protector link her to Clorinda via a net of textual and subtextual associations. Armida's mother bears the name of the character from Heliodorus' Aethiopica (An Ethiopian Romance) whose history parallels Clorinda's in some significant ways: Cariclia. ${ }^{10}$ This link might seem incidental, even irrelevant, to some readers. But I insist on its importance because Clorinda is a figure around whom many of the associations with Tasso's parents appear to converge. ${ }^{11}$ Armida appropriates names that mark her, as Clorinda is marked, as an "orphan" whose true identity and mission remain to be realized. As orphans, both Armida and Clorinda clearly exercise a fascination on a poet obsessed with family romance.

How then can one undo Armida's web of fascination? Certain possibilities have been suggested in Renaissance epic poems which precede Tasso's, mainly the Orlando furioso. In Canto 6 of Ariosto's poem, we find a sorceress/seductress, Alcina, who is part upperclass Renaissance courtesan, part alchemist and part Circe. She takes lover after lover, and transforms them into plants and animals when she tires of them. She manages to distract some of the principal knights in the Christian camp-notably Ruggiero, who falls prey to her despite the fact that Astolfo has given him fair warning. Alcina's power over the Christian soldiers lies in her use of magic to create a beautiful illusion. Ruggiero can not see, or refuses to see, her magical deceptions. He is quite taken by Alcina's favors and by the pleasures of her palace, and only after some time realizes vaguely that Alcina, bored by him as by her previous lovers, is about to make him join the company of other plants and animals in the forest. Alcina's magic works to render Ruggiero's vision, simple and human as it is, insufficient. Her company makes him more feminine, softer. The remedy proposed in Ariosto's poem is magic-magic as the control of illusion. Alcina's magic is destroyed only when Melissa, hired by the worried Bradamante to help save Ruggiero from Alcina's clutches, arrives with the magical ring to undo Alcina by destroying her magic, her sexual attractions and her palace. Thus, Ruggiero 
can not see what Alcina really is because she uses magic to her advantage; he needs a more powerful magic in order to surpass her. Melissa, however, does not simply appear with the ring and dispel all illusions. She takes the form of Ruggiero's mentor, Atlante, and in this guise, offers Ruggiero the ring, which works to reveal Alcina as quite the opposite of the young and beautiful woman she had created herself to be.

This technique of unmasking is a favorite of Ariosto's in the Orlando furioso, at least where magic is involved. It is important to note however that the gesture of unmasking respects gender difference. When the paladins come under the spell of Atlante, they are rescued by another paladin who manages to destroy the trappings of magic and expose the great and powerful (male) magician. Atlante is twice overcome in the Orlando furioso: once by Bradamante's cleverness and strength in Canto $4.25 \mathrm{ff}$., and finally by Astolfo and his horn in Canto $22.20 \mathrm{ff}$. When he flees from the magic horn, he is described merely as "pallido e sbigottito" (22.21.7), but when Bradamante pins him to the ground in Canto 4, she gets a good look at him. Here the magician appears a benign little old man, "un venerabil vecchio in faccia mesta" (4.27.6), trying in his bumbling way to exercise his limited power. When the source of magic is female, however, the exposé is specifically erotic, and relies, as we have seen, on the topos of the enchantress turned hag. ${ }^{12}$

The graphic unveiling of the sorceress/ seductress Acratia in Book 5 of Trissino's Italia liberata dai Goti (1547-48) falls into the latter category. Acratia's magic is associated with youth and sexual power, and is dispelled as Traiano rips off her robe in order to break her spell over Corsamonte and his companions:

... il buon Trajano,

Che Acratia in braccio avea, levò la gonna

Di lei, mostrando le secrete parti.

Come a quei Cavalier furon scoperte

Quelle brutture, che coprian le veste;

E le vider le coscie esser due biscie

Di fiero aspetto, e d'indi uscirne un lezzo,

Che superava ogni altra orribil puzza;

Quasi svegliati da mortal letargo,

$\mathrm{Si}$ risentiro, e si disciolse il velo,

Che gli era stato intorno a gli occhi avolto,

Onde l'un l'altro subito conobbe. $(47)^{13}$ 
No one in the Gerusalemme liberata ever uses such a technique of exposing Armida, despite the presentation of her as a manipulator of appearances. As a result, she continues to present, for the critics and to some extent for Rinaldo, an interpretive problem. It is never quite clear what she is: sorceress or mere woman, and as woman, Machiavellian seductress, enamoured consort, or abandoned victim. Nor is it clear how to read the sudden change in Armida's character that accompanies her conversion to Christianity at the end of the poem. The sense of being able to locate the real Armida fades as the poem progresses and Armida's image as virile and crafty operator is superseded by the portrait of her narcissism, which in turn is cancelled by her conversion at the end of the poem.

There can be no facile demystification of Armida similar to the unmasking of sorceresses and seductresses in previous Renaissance epic poems for the simple reason that Armida is not only she who deceives, but also she who perceives. Revealing Armida's duplicity does not suffice to dismiss the threat she poses to the Christians; it is also necessary to acquire new powers of perception at least as good as (or better than) those of Armida and to reveal the possible limitations of Armida's powers. Thus, Rinaldo is freed from Armida's spell in the moment when he gazes upon himself in the shield Carlo and Ubaldo bring to him (16.30-31). By gazing upon himself in the adamantine shield, Rinaldo appropriates powers of perception which were foreign to him as long as he remained an unconscious youth, and is able to make his way out of the solipsistic and labyrinthine environment in which he lived his love for Armida. Moreover, these new powers of perception are portrayed as superior to Armida's as well, since Armida's observatory powers throughout the description of her in her own residence on the Fortunate Islands, have been represented in terms that recall the Narcissus myth. ${ }^{14}$ Rinaldo's "victory" over Armida is in a sense more profound than Ruggiero's escape from Alcina. Ruggiero's discovery that Alcina is a hag rather than an enchantress allows him to attribute to her a gross deception rather than having to admit his own inadequate perception. Since his liberation from Alcina takes place at a superficial level, which does not touch the heart of the problem, he continues to be prey to similar deceptive traps for some time. ${ }^{15}$

The peculiar and lasting bond between Rinaldo and Armida results 
from the absence of a facile demystification. The emphasis, in the case of Rinaldo and Armida, has been shifted onto a reevaluation of the moment of perception, and the socialization of the subject. Debasement of the opposition would soon be revealed as facile, since the opposition has, at least in certain moments, perceptive powers which are superior to those of the Christian warriors, even if at other times, the powers of the opposition are rendered as dangerous because they present a threat to society and to religion. As Maggie Günsberg points out, Rinaldo's love for Armida remains valid as long as it is redefined within the context of the ideals of his religion and society: "sarò tuo cavalier quanto concede / la guerra d'Asia e con l'onor la fede" (16.54.7-8) (38). And Armida's story, originally told to deceive the Christian warriors, is never shown to be a mere fable; at the end of the poem, it seems that Rinaldo still believes Armida's story, or at least part of it, when he promises her, "Nel soglio, ove regnàr gli avoli tuoi,/ riporti giuro” (20.135.3-4).

Günsberg has also noted that Armida's character is problematic because she does not comply with Aristotelian rules Tasso himself espouses in his Discorsi del poema eroico, since she undergoes a change in character and she "outwit[s] a male character" (37). I think, however, that if we consider Armida's powers, which are neither simply magical nor simply sexual, nor unredeemably narcissistic, we may come to some conclusion about why it is so difficult for Tasso (or Rinaldo) to dismiss her.

Consider the presentation of the sorcerer Atlante in the Orlando furioso. As David Quint argues, Ariosto appears to have conceived of Atlante as a surrogate figure for Boiardo (81). Thus, the unmasking of Atlante appears to be a result of a struggle between Ariosto and a literary predecessor he never explicitly acknowledged in his poem. Ariosto's refusal to confer power on Atlante appears to be his way of distancing himself (somewhat anxiously) from the author who provided him with the basic source for his poem.

It is valuable to keep in mind Ariosto's treatment of the sorcerer Atlante as we reconsider Tasso's treatment of the sorceress Armida. We know that Armida possesses sexual charm and a control that comes from her manipulation of magical arts and we know that Armida is made to surrender. But if we consider Armida's specific magical powers and the way in which she is made to surrender, I 
think we will see that there appears in Tasso a desire to appropriate female magical powers, rather than to dismiss them.

When Armida actually does use her magical powers, she turns her victims into fish: animals noteworthy to Tasso himself as lacking the ability to make sound. ${ }^{16}$ In the following passage, Guglielmo tells his fellow Crusaders of his experience in Armida's residence:

Con una man picciola verga scote, tien l'altra un libro, e legge in basse note.

Legge la maga, ed io pensiero e voglia sento mutar, mutar vita ed albergo.

(Strana virtú!) novo pensier m'invoglia: salto ne l'acqua, e mi vi tuffo e immergo. Non so come ogni gamba entro s'accoglia, come l'un braccio e l'altro entri nel tergo, m'accorcio e stringo, e su la pelle cresce squamoso il cuoio; e d'uom son fatto un pesce.

Cosí ciascun de gli altri anco fu vòlto e guizzò meco in quel vivace argento. Quale allor mi foss'io, come di stolto vano e torbido sogno, or me 'n rammento.

Piacquele al fin tornarci il proprio volto; ma tra la meraviglia e lo spavento muti eravam.... (10.65.7-67.7)

Remember also that when Tancredi is finally trapped in Armida's castle, the narrator compares him to a fish $(7.46-47)$. The threat posed by Armida is that of the anti-rational and the non-verbal. In keeping with this, her arsenal of weapons includes the fountain of laughter, and among the living presences on her island is the parrot who calls to love, but whose control of the linguistic medium, like that of all birds, is necessarily limited (16.13-16).

Armida's power is to be attributed not to magic per se, I think, but to her able presentation of herself, and to her expert silencing of others. Thus the image of Armida with her magic wand is not a particularly powerful or interesting one. Indeed, it is the image of Armida with a book that seems to express much more appropriately the power Armida exercises. Everything pivots here on the question of linguistic control and control of texts. Armida is successful in large part because of her control of the story of her origins. In contrast to Clorinda, who rebels against the story of her origins that Arsete reveals to her in Canto 12 of the poem, Armida recounts 
a story which no one ever negates, and which maintains its validity despite the contradictions she herself brings forth in the course of her lament in Canto 16. Her power is a source of great fascination to a poet who had a significant investment in questions regarding genealogy. ${ }^{17}$ To the extent that the poet sees the power to define one's own genealogy as overweening, he brings Armida back into an orthodox political and Christian line. Armida submits to Rinaldo with words that some critics have found offputting. Frequently quoted is Giamatti's comment:

But when Rinaldo asks Armida to forsake paganism (XX, 135), and she replies:

Ecco l'ancilla tua: d'essa a tuo senno

dispon, (136)

we wince. This echo of the words of Mary to Gabriel in Luke 1:38 ("Ecce ancilla Domini, fiat mihi secundum verbum tuum" in the Vulgate) is too forced. Indeed, there is something desperate here in Tasso's effort to bring Armida into line with Christianity. The shift implied by these words is too great, and we are finally unconvinced of Armida's redemption. The inner conflicts which were dramatized so beautifully in the garden remain to haunt the poem. (209-10)

Although I agree that the resolution is tenuous, I also believe that Tasso's choice of this particular Biblical phrase is logical and possibly even predictable, given the threat Armida poses.

Let us consider Armida's fate after she converts, at Rinaldo's request, in Canto 20. Some readers take Armida to be Rinaldo's future spouse and a matriarch of the illustrious Este family line, the result of a marriage that takes place outside the action of the poem, presumably to avoid detracting from the importance of the liberation of Jerusalem. Others, however, are not at all convinced that Armida finishes her days in the house of Este. ${ }^{18}$ The disadvantages to proclaiming loudly the origins of this dynasty are self-evident, and the creation of such a dynasty (if indeed it exists) must be played down. Thus, the Magus of Ascalona is silent on the issue of Rinaldo's marriage, as he is in general on that of Rinaldo's offspring.

I think that it is important that, as in the case of Erminia, there is no clear resolution of Armida's fate, while at the same time the reader is encouraged to assume that marriage might be the outcome. In order for Tasso to overcome the threat Armida poses when she fashions her own genealogy in a way which proves dangerous to the 
Christian enterprise, and to authority in general, marriage must be at least suggested, for marriage here is the sign that Armida accepts a genealogy in which her role is a submissive one. Armida speaks words of atonement which communicate her submission to a higher authority, to Rinaldo as earthly representative of the Christian God. Her echo of the Biblical "ecce ancilla Domini" suggests her acceptance of a divinely sanctioned genealogical plan, be it the one Tasso imagined for Rinaldo and the House of Este (if we accept the idea of a marriage between Rinaldo and Armida), or the genealogy of the Son of God (if we accept only the idea that Armida converts to Christianity). By echoing the words that permitted the mystery of the Incarnation, Armida submits to a Christian order founded on a genealogy incomprehensible to human reason; but her use of these words preserves for her a privileged role in the founding of such a mystery. The node of problems presented by Armida's tale of an unusual genealogy remains to haunt the reader.

Cornell University

\section{NOTES}

1 All quotations from Tasso's Gerusalemme liberata are from Caretti's edition.

2 Zatti (42-43) and Iovine (47-51) have also noted this resemblance.

3 Getto comments on the striking presence of natural images in the descriptions of Armida in Canto 4 (193-94).

4 Giamatti notes that "The City is the way to eventual inner redemption through physical conflict, Nature the way to immediate inner peace through avoidance of physical struggle" (184). As Giamatti also points out, "Throughout the poem, Armida is the figure who represents all that is inimical to the City and Christian endeavor" (184).

$5 \mathrm{I}$ am indebted to Beverly Ballaro for this observation.

6 See Getto 205: "Il Tasso è un poeta sempre attento agli occhi, a questo specchio delle passioni, a questa indefinita zona d'incontro di corporeità e spiritualità, una zona che è poi quella in cui ama muoversi la sua ispirazione."

7 Goffredo's ideal would be the ruler at the end of Molière's Tartuffe. Molière's sovereign has an eye sure and unwavering, and immediately distinguishes the good guys from the bad, who are in the final scene borne off to prison.

8 See Aeneid, 1.353-59:

ipsa sed in somnis inhumati venit imago coniugis ora modis attollens pallida miris, crudelis aras traiectaque pectora ferro nudavit, caecumque domus scelus omne retexit, tum celerare fugam patriaque excedere suadet 
auxiliumque viae veleres tellure recludit

thesauros, ignotum argenti pondus et auri.

[But in her sleep came the very ghost of her unburied husband; raising his face pale in wondrous wise, he laid bare the cruel altars and his breast pierced with steel, unveiling all the secret horror of the house. Then he bids her speed flight and leave her country, and to aid her joumey brought to light from earth old-time treasures, a mass of silver and gold known to none.]

9 See Aeneid, 2.270-79, 287-89:

in somnis, ecce, ante oculos maestissimus Hector

visus adesse mihi largosque effundere fletus, raptatus bigis, ut quondam, aterque cruento

pulvere perque pedes traiectus lora tumentis. ei mihi, qualis erat! quantum mutatus ab illo Hectore, qui redit exuvias indutus Achilli, vel Danaum Phrygios iaculatus puppibus ignis! squalentem barbam et concretos sanguine crinis volneraque illa gerens, quae circum plurima muros accepit patrios!

$$
[\ldots]
$$

ille nihil, nec me quaerentem vana moratur, sed graviter gemitus imo de pectore ducens, 'heu! fuge, nate dea, teque his,' ait, 'eripe flammis.['] [In slumbers, lo! before my eyes there seemed to stand Hector, most sorrowful and shedding floods of tears; tom by the car, as once of old, and black with gory dust, his swollen feet pierced with thongs. Ah me! what aspect was his! how changed from that Hector who retums after donning the spoils of Achilles or hurling on Danaan ships the Phrygian fires! with ragged beard, with hair matted with blood, and bearing those many wounds he gat around his native walls ... He replies naught, nor heeds my idle questioning, but heavily drawing sighs from his bosom's depths, 'Ah, flee, goddess-bom,' he cries, 'and snatch thyself from these flames. ...']

10 In the Gerusalemme conquistata (5.45), Tasso cancels Cariclia's name from Armida's tale and leaves only the name of her father, Arbilano. But if the association with Cloninda seems erased by this move, it reappears elsewhere: Tasso changes from "Arimone" to "Arbilano" the name of the warrior whom Clorinda kills in the moment when she is locked outside the walls of Jerusalem. (See Gerusalemme liberata, 12.49.1-4 and Gerusalemme conquistata, 15.62.1-4.)

Moreover, Armida's protector in her tale of woe is named "Aronte," like the warrior in Virgil's Aeneid who plays a crucial role in the life of the virgin warrior Camilla, considered to be the prime figure in Clorinda's literary genealogy.

11 See Ferguson 62,74 , and $126 \mathrm{ff}$.

12 The most powerful early example of unmasking is to be found in Purgatorio 
19, where the femina balba Dante has imagined to be an enchantress turns out to be a nauseating sight: " $L$ 'altra prendea e dinanzi apria / fendendo i drappi, e mostravami 'l ventre; / quel mi svegliò col puzzo che n'uscia" (Purgatorio, 19.31-33).

Spackman discusses the topos of the enchantress turned hag, and its use as an attack on artifice and rhetoric (160-64).

13 Spenser's Duessa is exposed in a very similar manner, see The Faerie Queene, 1.8.45-50.

14 See Giamatti 203 ff.

15 Similarly, psychoanalysis distinguishes between a superficial resolution of a problem, which causes the symptom to disappear but which does not block production of other symptoms, and a cure which rids the patient of the mechanism causing symptom formation.

16 See the description of the creation of the fishes, and the comparison of their ability to make sounds with that of men and other animals, in Tasso's Il mondo creato, Quinto Giomo, lines $144 \mathrm{ff}$.

Alcina too transforms her former lovers into animals, fountains, rocks, and so forth, precisely in order to prevent them from revealing any information about her. Oddly enough, it is Astolfo-plant who tells Ruggiero about Alcina; but of course Ruggiero doesn't believe the story when he actually lays eyes on the charming Alcina. In any case, we see here that there exists already in the genealogy of epic sorceresses the idea that metamorphosis serves to silence the unlucky contestants.

17 The question of genealogy is one that is, as Margaret Ferguson has shown, crucial for Tasso.

18 Many commentators, especially in their summaries of the poem, simply do not deal with this issue (suggesting that they do not interpret Rinaldo's words as a marriage proposal), or phrase their summary in language as ambiguous as Tasso's. Thus, Caretti in the summary of Canto 20 in his edition of the Gerusalemme liberata presents Rinaldo in the best light possible, saying "... . Rinaldo compie prodigi di valore, vendica Sveno e infine conquista il cuore di Armida, a lui amorosamente arresasi." Chiappelli, in his edition of the Gerusalemme liberata, limits himself to saying that Rinaldo reconciles himself with Armida. Angelo Solerti, on the other hand, in his summary of the Gerusalemme liberata and the Gerusalemme conquistata published at the end of Bonfigli's edition of the revised version of the poem, says explicitly that "Rinaldo insegue Armida che stava per uccidersi; la salva e le promette di sposarla nel regno (121-126)" (2: 407).

Robinson emphasizes the lack of information about Armida's life after the poem, and says, "If marriage was inconceivable for Erminia and Tancredi, it is all the more so for Armida and Rinaldo, given their voluptuous history and his destruction of the enchanted wood" (285).

Fichter, who exalts Rinaldo and Armida as the dynastic couple of Tasso's poem, does not seem to have a trace of a doubt about Armida's fate (112 ff.). 


\section{WORKS CITED}

ALIGHIERI, Dante. La Commedia secondo l' antica vulgata. Ed. Giorgio Petrocchi. 4 vols. Milano: Mondadori, 1966-67.

ARIOSTO, Ludovico. Orlando Furioso. Ed. Lanfranco Caretti. Torino: Einaudi, 1971.

DELlA PORTA, Giovanni Battista. Della fisonomia dell' huomo. Padova: Pietro Paolo Tozzi, 1623.

FERGUSON, Margaret W. Trials of Desire: Renaissance Defenses of Poetry. New Haven: Yale UP, 1983.

FICHTER, Andrew. Poets Historical: Dynastic Epic in the Renaissance. New Haven: Yale UP, 1982.

GETTO, Giovanni. Nel mondo della "Gerusalemme". Firenze: Vallecchi, 1968.

GIAMATTI, A. Bartlett. The Earthly Paradise and the Renaissance Epic. Princeton: Princeton UP, 1969.

GÜNSBERG, Maggie. "The Mirror Episode in Canto XVI of the Gerusalemme Liberata," The Italianist, 3 (1983), 30-46.

HELIODORUS. An Ethiopian Romance. Trans. Moses Hadan. Ann Arbor: U of Michigan P, 1957. Rpt. Westport: Greenwood P, 1976.

IOVINE, Francesco. La "licenza del fingere": Note per una lettura della "Liberata." Roma: Bulzoni, 1980.

QUINT, David. "The Figure of Atlante: Ariosto and Boiardo's Poem." MLN, 94 (1979): 77-91.

ROBINSON, Lillian S. Monstrous Regiment: The Lady Knight in SixteenthCentury Epic. New York: Garland Publishing, Inc., 1985.

SPACKMAN, Barbara G. "Gabriele D'Annunzio and the Rhetoric of Sickness in Decadentism." Diss. Yale University 1984.

SPENSER, Edmund. The Faerie Queene. Ed. Thomas P. Roche, Jr. and C. Patrick

O'Donnell, Jr. New Haven: Yale UP, 1981.

TASSO, Torquato. Gerusalemme Conquistata. Ed. Luigi Bonfigli. 2 vols. Bari: Laterza, 1934.

. Gerusalemme Liberata. Ed. Lanfranco Caretti. Torino: Einaudi, 1971. . Gerusalemme Liberata. Ed. Fredi Chiappelli. Milano: Rusconi, 1982. Il mondo creato. Ed. Giorgio Petrocchi. Firenze: Le Monnier, 1951.

TRISSINO, Giovanni Giorgio. L'Italia Liberata dai Goti. In Tutte le opere di Giovan Giorgio Trissino. Verona: Jacopo Vallarsi, 1729.

VIRGIL. Aeneid. In Virgil. With English trans. by H. Rushton Fairclough. Loeb Classical Library. Rev. ed. 2 vols. London: Heinemann, 1969.

ZATTI, Sergio. L'uniforme cristiano e il multiforme pagano: Saggio sulla "Gerusalemme Liberata." Milano: Il Saggiatore, 1983. 